\title{
'Where are the buses?' - Role of Geography Fieldwork in a Socially Fragmented World
}

Ooi Giok Ling

National Institute of Education, Singapore

giokling.ooi@nie.edu.sg

In a world that is increasingly fragmented and polarised, fieldwork becomes far more important than ever before in understanding social and cultural differences. This paper considers the role of fieldwork in geography for students from small countries like the city-state of Singapore as well as the understanding of political and economic differences that exist in the region. Socialised into a highly planned urban environment in which public goods and services are taken for granted such as urban transport networks that are crucial in the functioning of cities, final year university students majoring in geography from the National Institute of Education found themselves highly challenged in locating similar urban provisions in their fieldwork site in neighbouring Malaysia. 'Where are the buses?' was the first question posed by a group once they had reached the island of Pulau Langkawi, off the northwestern coast of Peninsular Malaysia. The assumption underlying the question was that other worlds would not be too different from that which the students are familiar - the well-organised and well-planned citystate of Singapore. Post-structuralists suggest that education is a process through which subjects are formed while formal education in most countries can be considered to be a 'state project' since it is based on national school curricula. Foucault's concept of governmentality concerns how states determine the types of knowledge and practices that are to be communicated to students and hence, create the support for the state's developmental agenda and its rationalisation. This paper argues that fieldwork is crucial in the development of critical thinking and students' understanding of the geographies of an increasingly fragmented world.

Keywords: Fieldwork; globalised world, social fragmentation; critical thinking; governmentality

Geography fieldwork at the tertiary level remains important in developing countries but in Singapore, it appears to be a far more crucial aspect of education as the discussion which follows is aimed at establishing. The importance of fieldwork has never been greater for geography students to understand their increasingly fragmented world. 'Real geography' as highlighted in the United Kingdom, "began as pupils gained an understanding of how people in simple societies overseas lived" (Fairgrieve, 1908, pp. 247-249). Fieldwork within the United Kingdom itself in the beginning of the $20^{\text {th }}$ century was considered important because of the polarised stereotype that counterpointed the ills of the town with the good of the countryside. In other words, fieldwork was deemed crucial in a polarised world then. 
Fieldwork in geography is usually expensive to organise and a challenge to teaching staff who have to secure the resources for the field trips. Views about the contributions that fieldwork makes to geography and geography education vary considerably depending on where fieldwork is being conducted by geography faculty and their students.

- Some geography fieldwork has sought to achieve national education goals on wide constituencies ranging from parents to the specific groups in society.

- Other fieldwork has been conducted to ensure that the students see for themselves and experience the impact of events that the textbooks are trying to communicate.

- Other fieldwork projects aimed at providing students of geography with an understanding of the differences that exist among societies and cultures in places other than those with which they are familiar.

According to critical reviews, however, few studies in geographical education and apparently even fewer in fieldwork have been concerned about what the teacher intended to achieve in a programme (Lai, 2000). Rather, the focus has been on the learning experiences of students in the programme as well as what the students actually picked up from the programmes (Marton \& Booth, 1997). Furthermore, in fieldwork, the tension has been noted between the teachers' desire to transmit geographical knowledge and the recognition of the role as well as relevance of learning from experience (Boud, Cohen \& Walker, 1993).

The importance of fieldwork as learning through actual experience by students is emphasised for geography education when students study geography in small countries and relatively affluent societies like that of the tiny city-state of Singapore. In the following discussion, the focus is on final year geography student teachers in a Singapore university who are required to do a core module on fieldwork in geography. "The students we teach in geography classrooms are growing up in a world of stark contradictions. While prevailing forms of development continue to bring considerable benefits such as greater life expectancy, more gender and racial equality, and some extension of political freedoms, there is growing evidence of ecological degradation, economic as well as political instability, social exclusion, loss of cultural diversity and psychological insecurity" (Huckle, 2001). So if geography does suggest to young people that they need to recognise their location in a 'borderless' world, it does not do so in a singular and uncontested way (Morgan, 2001).

There are significant differences between the field site and the home country of the Singapore students. Singapore's per capita income is among the highest in the world whereas the island of Pulau Langkawi in the northwestern coastal area of Malaysia, a 45-minute flight away, was a place with relatively lower incomes where people continue to earn a living from farming and fishing (see Figure 1). Fieldwork objectives that the lecturers intended were to highlight the social and cultural development on the island of Pulau Langkawi. These objectives implied the translation of fieldwork goals into processes of engagement with the differences and the reality of everyday urban living and its tensions in Pulau Langkawi. These differences make up the reality from which the students in Singapore are removed not only in developmental but also political terms. The latter includes the staging of street protests and demonstrations in Malaysia which are political measures that students would not witness at all in Singapore since they are prohibited by law.

Fieldwork in geography underscores the importance of understanding differences between places. These are not only differences in physical geography but those that reflect wider societal processes that are at work in different places. In the fieldwork that was organised for the final year university geography students at the National Institute of Education, the objective was mainly to initiate the student teachers into the planning and 


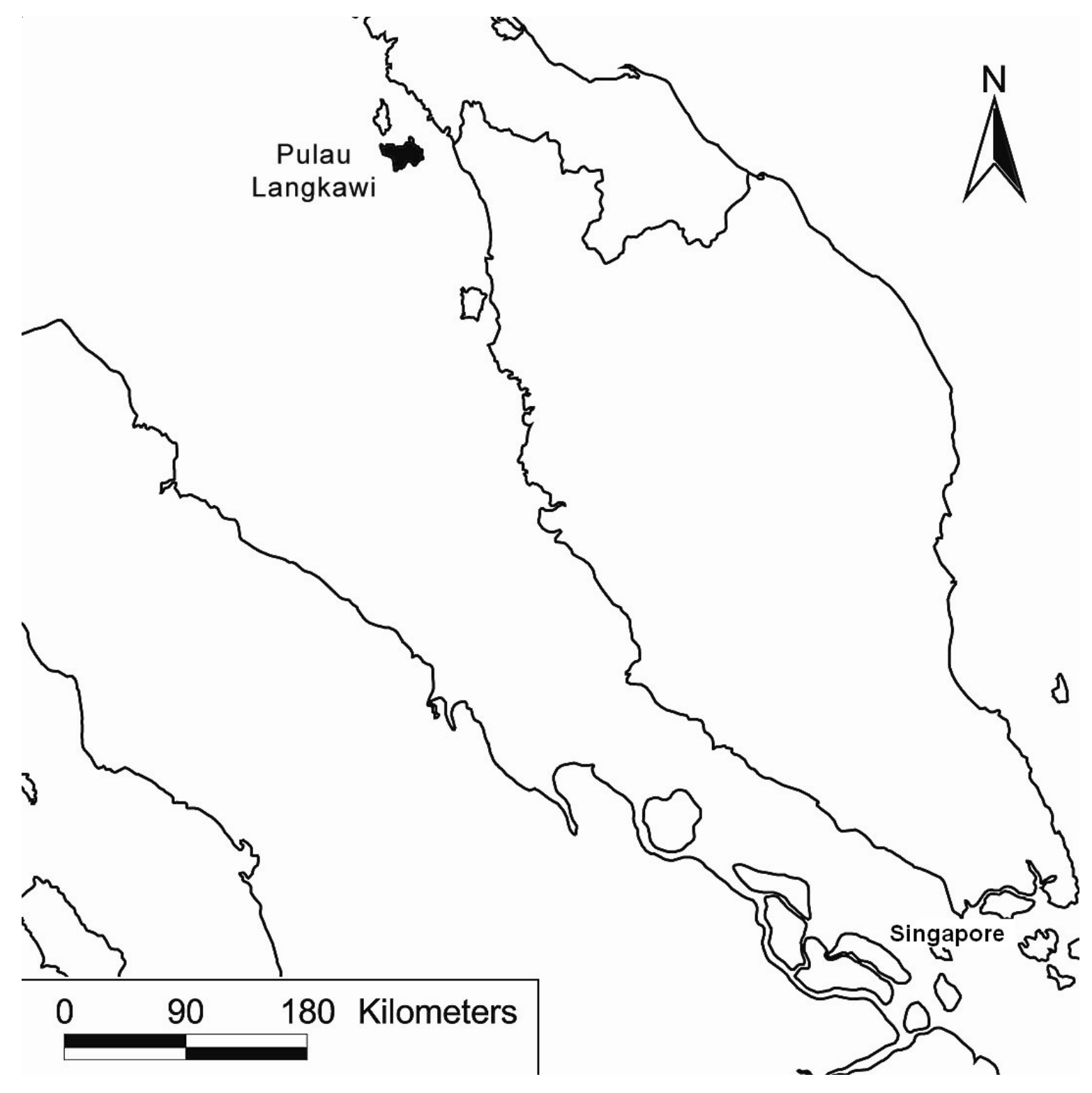

Figure 1.

Location of Pulau Langkawi and Singapore

implementation of work out in the field site. Such work entailed collection of both primary and secondary information as well as the analysis and interpretation of this information to understand the development issues under review. Student teachers worked in groups of three to four people when they were conducting the fieldwork but were solely responsible for the data or information gathering required for individual fieldwork project reports to be submitted.
The student teachers learnt about the differences between places such as the population sizes, 'market catchments' and , the different perspectives on the development of a public bus transport system. While the economic factors determining decision-making remained similar in terms of the viability of running a public bus service in both places - Singapore and Pulau Langkawi, student teachers learnt that there are alternative perspectives that can lead to different urban development outcomes. 
The construction of place is an active process that is usually conducted through broader relations of power (Harvey, 1993). The study of places therefore cannot be separated from an understanding of the wider political and policy debates that have shaped decisions made by a society, and Massey (1999) has encouraged geography teachers to unpack or 'deconstruct' ideas of the local community in order to develop a more open or 'progressive' sense of place. Indeed, in preference to drawing boundaries around places and emphasising their unity or coherence as territory, Massey envisions the tracing of the webs of social relations that stretch out around the globe.

Geographical fieldwork that was undertaken by the geography student teachers was aimed at a number of learning outcomes not only for the students but also the lecturers. These include the identification of study objectives, and the understanding of concepts and procedures with which such objectives can then be translated to fieldwork methodologies such as interviews and surveys as well as observations. The benefits of undertaking fieldwork according to geography educationists (Harvey, 1991) are more apparent in terms of the case-study aspects as well as in the challenges that students can rise up to. According to Foucault (1988), the state can, through education, develop subject positions through which the individual negotiates relations to the rule. Subjects however, can choose to either embrace, enact, resist or reject subject positions (Allen, 2003). Fieldwork has a role of generating discourses which allow these shifts in subject positions that students can then choose to undertake.

Teamwork is seen as one among the benefits derived from the carrying out of fieldwork. In other words, fieldwork in geography education implies the capacity for team work and mutual help in order to realise the goals set out in the beginning with the identification of the study project.

\section{FIELDWORKAND LEARNING FROM DIFFERENCES}

Useful knowledge is continually refined by reflecting upon the results of applying academic and lay ideas to action (Dickens, 1996). While fieldwork has been criticised when it is organised as little more than a tour and students remain largely passive and assume the roles of tourists, properly organised fieldtrips can provide students with experiences, knowledge, understanding as well as skills that are important to an understanding of the world around them. Yet, as research on fieldwork carried out by schools has highlighted, there can be huge gaps between intentions and practices in the organisation of fieldtrips. While schools and universities are urged to organise fieldwork as a teachinglearning process taking place in a unique learning environment, that is, the fieldwork site, the experiences gained can be limited because of the challenges in translating intentions into practices in the field.

The premise that space is contested terrain provides the entry point for students doing fieldwork in a different place by presenting the means with which to engage the differences observed at the field site. There is concern that such engagement could lead to an essentialised and crude dualism - developed and developing areas - much like the way in which the world has been divided. The consequences would be to render such dualism as unproblematic (Edwards, 2001) as well as promote a 'developed country' and superior perspective of the differences in the world and in turn, pre-empt other ways of studying and considering these differences. Ultimately, the students might commit the error of a Rostowian trajectory of development that explains the differences in developing countries as the gaps that have to be closed by these countries when they catch up with the developed ones. 


\section{ENGAGING WITH DIFFERENCES AMONG PLACES}

In the field, the final year university students from Singapore learnt about differences in urban living environments in a routine and everyday activity how to get to work and where one needs to be in the course of everyday life. The fieldwork site in the northwestern part of Malaysia on Pulau Langkawi was a contrast to Singapore in terms of urban development and particularly in urban modes of transport. Mobility was largely arranged through private transport modes compared to the public transport system that the students were familiar with in Singapore.

Pre-fieldwork discussions can be used to prepare fieldworkers of the differences they must expect when they work on a field-site that is different from the familiar environments in which they live particularly if the students are from 'First World' countries and are travelling to developing countries (Sidaway, 1992; Willis, 2003). Such discussions or preparatory work can improve the means through which students can engage with events they are witnessing while in the field such as a demonstration by workers against their employers. Such events were particularly challenging to the university students from a citystate where such demonstrations are prohibited.

Conceptual understanding is derived most effectively by learning from what the real world can teach. There is a well-known adage among geographers that 'dirty boots beget wisdom.' Differences are highlighted in how the developing world is taught by teachers with and without field experience. Teachers who lack direct experience of the developing world usually focus upon knowledge and information-based aims and practices. With increasing confidence, this eventually progressed into a focus on values, based on consideration of the images of the locality in a cultural context. Finally, teachers with experience of the developing world use development education methods to provide experiences for learners in order to develop critical thinking skills... (Walkington, 1999).
In various ways, fieldwork fulfils many of the goals that schooling is meant to address apart from the intellectual, academic and technical achievements, such as "the development of insight and empathy; the encouragement of creativity and imagination; critical reflection about social and personal values" (Saunders, 1998, p. 8). This is because different stages of fieldwork are interconnected such that the proper conduct of each stage is necessary to ensure the realisation of the benefits that are expected. The learners have to map out to a large extent the information they will need to gather in relation to the presentation of such information when they are subsequently working on communicating what they have learnt in the field.

The goals of fieldwork appear to be best achieved if the stages involved in the enabling of active learning capacity of students are clearly incorporated in the process of engaging with the field site, its population, and the issues under review. These stages concern pre-fieldwork learning, carrying out fieldwork itself and postfieldwork analysis and reflection. Furthermore, these stages in the fieldwork process are likely to have greatest impact if the curriculum has provided adequate support for such learning experience by the students in the field site. In this way, fieldwork in geography bridges not only text and reality but also the learning and understanding of differences. This is particularly the kind of reality that students have to understand in an increasingly fragmented world, one that is polarised between poor and rich and the privileged and disadvantaged.

\section{UNDERSTANDING THE SPATIALITY OF DIFFERENCES}

Fieldwork tasks for the students, and this is well-put by Tochan and Munby (1993), are not to produce an 'activity' in which the 'pedagogic adventure' predominates, but rather to research and develop an aspect of subject knowledge, using their disciplinary expertise to provide an introductory description and explanatory account, 
and then to clarify and make useful distinctions for the young learner (Machon \& Lambert, 2001). The fieldwork tasks can be considered in a sense, as designed to promote the development of what some educators have proposed to be called 'subject didactics' (Lambert, 1999), using a subject discipline to shed light on and account for, events, concepts and processes and thus help learners make sense of the world and the differences as well as linkages to be found among varied places.

The final year students who were at their field site in Pulau Langkawi found that in contrast to Singapore, there was no public bus transport infrastructure on the island. Apart from a taxi service owned entirely by the private sector, the residents got around the island in their own cars or took these taxis. Through the fieldwork that was done, these students then understood the contrasts in public policies and their impact on the organisation of urban transport services.

Although tourism was important in both Singapore and Pulau Langkawi and despite the fact that both are islands, these similarities were the premises for the contrasts which faced the students during their field trip. Not only were the population bases different in the two places, but also the number of tourist arrivals in both. The scale at which urban transport services had to be organised was one of the major differences between the two places.

In the course of conducting fieldwork, the students needed to criss-cross the island and move between urban and rural areas. Doing their fieldwork meant also adjusting to the use of private modes of transport like rental cars. The convenience of the use of such services was experienced by the need of the students to contact the car rental firms and arrange for the delivery and return of the rental cars.

At the same time, the students also conducted interviews with the local agency that had in the past provided public bus transport services and was continuing to operate school bus services for children attending both primary and secondary schools on the island. These interviews highlighted to students the economic reasons for terminating the public bus transport services on the island. Among these were costs, low patronage, and the lack of financial support to sustain the public transport services. School bus services had continued because these were more economically viable than the public bus services that had been provided.

The learning that the students had showed that they were more responsive to the traditional descriptive and explanation approach (Fuller, Rawlinson \& Bevan, 2000) rather than to the analytical and predictive. Students accepted with critique the lack of a public transport service and faithfully reported the level of satisfaction among tourists with the prevailing modes of transport provided on the island of Langkawi. Since satisfaction levels were relatively high, the conclusion that was drawn was that the lack of public transport notwithstanding, the island's population and its tourists could manage with private modes of transport like taxis and car hire because car ownership and use of the car were preferred by the local people.

Beginning with their question of where are the buses because these are an indispensable feature of urban transport in Singapore, students had adjusted to there being no such public transport services on Pulau Langkawi. The lower level of urbanisation on the island and the island being only half the size of Singapore might have been the factors considered in the adjustment to this key difference in urban transport organisation between Singapore and Pulau Langkawi. The total population in Pulau Langkawi was 70,000 and the number of tourists as well as visitor arrivals was estimated at around 900,000.

While the students learnt about differences, the challenge lay in engaging them with the analysis and interpretations of these contrasts among places and how aspects of urban life such as, transport, were being organised. In a way, the fieldwork approach in itself did not provide the means with which to engage the students with the relevance of the work they were doing to the more critical and radical social and cultural geography being taught in universities today (May, 1999). Fieldwork that is 
done in geography can be largely empirical and experiential, with a heavy emphasis on adjusting to the differences that are found at the field site. While Kolb's experiential learning theory is one of the best known educational theories in higher education (Healey \& Jenkins, 2000), such learning relies on fieldwork being an intrinsic component of the geography curriculum.

Emphasis can be focused on the design of questionnaires in order to gather the data required from fieldwork. Students become preoccupied with the survey and completion of the questionnaires during their fieldwork. So while the arguments favouring fieldwork are that it bridges theory and practice, making the classroom come alive, engaging students in designing and carrying out research and hence, preparing them for the demands of higher education, it has not been very clear how the actual fieldwork fits into the overall geography curriculum (Goh \& Wong, 2000; Gerber \& Goh, 2000) or whether students are making the connections between text and reality.

The continued relevance of fieldwork lies in addressing the challenge of how students in university can bridge their understanding of the text through an experience of reality and in the process engage with the differences that they find at the field site. Such engagement however, has to be premised on a strong sense of inquiry and understanding of the issues being studied in the field such as urban transport in the case of the Singapore university students who did their fieldwork in Pulau Langkawi.

The difficulty in the processes of engagement with the real issues of urban transport development as a public good as well as a basic urban need was partly evident in the question that the students had first asked, 'Where are the buses?'. This question was prompted by the differences that they had found between the field site and where they were from in Singapore. In the effort to understand the reasons why there were no buses in Pulau Langkawi but only abandoned bus-stops scattered throughout the island, the Singapore students also had to relate to the different scales of governance in Pulau Langkawi. Being a city-state, Singapore's national government basically makes policy decisions that serve the urban and the local scales as well. In Pulau Langkawi, students had to engage with different agencies working at the national level as well as the local and engage with the tensions that exist between differing scales of governance.

The learning outcomes in the project reports that resulted from the fieldwork highlight the importance of curriculum support in engaging with the events that have never been part of their everyday reality while in Singapore. This would be curriculum which has familarised students with the processes of engaging with social and cultural differences among places. In turn, students were able to incorporate more effectively in their narratives the differences in social relations and everyday tensions in urban living that have never been the reality they faced in Singapore but which was very much in evidence in their field site.

\section{CONCLUSION}

In an increasingly differentiated as well as polarised world, fieldwork in geography provides a source of experiential learning that has never been more important. The challenge to the lecturers accompanying the students on their field-trip was to engage these students in the process of learning from and understanding implications of the different political conditions as well as social structure at the field site. Particularly in small and affluent societies such as that of Singapore's, fieldwork presents opportunities for students to engage in differences in everyday living and policy decisionmaking at different geographical scales that they are unlikely to come across in their own country.

\section{REFERENCES}

Allen, J. (2003). Lost geographies of power. Malden, MA: Blackwell.

Boud, D., Cohen, R. \& Walker, D. (1993). Using experience for learning. Buckingham: The Society for Research into Higher Education and Open University Press. 
Daniels, H. (Ed.) (1993). Charting the agenda: Educational activity after Vygotsky. London: Routledge.

Dickens, P. (1996). Reconstructing nature, alienation, emancipation and the division of labour. London: Routledge.

Edwards, G. (2001). A very British subject: Questions of identity. In D. Lambert \& P. Machon (Eds.). Citizenship through secondary education (pp.109-121). London: Routledge.

Foucault, M. (1988). The use of pleasure: The history of sexuality (Vol. 2). New York: Penguin.

Gadotti, M. (1996). Pedagogy of praxis, a dialectical philosophy of education. New York: SUNY.

Fairgrieve, J., (1908). Geography. In Adams, J.,(Ed.), The New Teaching (pp.230-262), London: Hodder and Stoughton.

Fuller, I., Rawlinson, S. \& Bevan, R. (2000). Evaluation of student learning experiences in physical geography fieldwork: Paddling or pedagogy? Journal of Geography in Higher Education, 24(2), 199-215.

Gerber, R. \& Goh, K.C. (Eds.) (2000). Fieldwork in geography: Reflections, perspectives and actions. Dordrecht, The Netherlands: Kluwer Academic Publishers.

Goh, K.C. \& Wong, P.P. (2000). Status of fieldwork in the geography curriculum in Southeast Asia. In Gerber, R. \& Goh, K.C. (Eds.), Fieldwork in Geography: Reflections, Perspectives and Actions (pp.99-117), Dordrecht, The Netherlands: Kluwer Academic Publishers.

Harvey, P.K. (1991). The role and value of ALevel geography fieldwork: A case study. Unpublished doctoral dissertation, University of Durham, Durham.

Harvey, D. (1993). Class relations, social justice, and the politics of difference. In S. Pile \& M. Keith (Eds.) Place and the politics of identity (pp.41-66), Oxford: Blackwell.

Healey, M. \& Jenkins, A. (2000). Kolb's experiential learning theory and its application in geography in higher education, Journal of Geography, 99, 185-195.

Huckle, J. (2001) Towards ecological citizenship. In D. Lambert \& P. Machon (Eds.). Citizenship through secondary education (pp.144-160). New York: Routledge.

Lai, K.C., (2000). Geographical fieldwork as emotionally engaged learning. Geographical Education, 13, 25-33.

Lambert, D. (1999, February). Teaching through a Lens: the Role of subject expertise and teaching in the fields of social and environmental education. A paper read at the International Conference on Teacher Education, Hong Kong Institute of Education.

Machon, P. \& Lambert, D. (2001). Citizenship denied: the case of the Holocaust. In D. Lambert and P. Machon (Eds.) Citizenship through secondary education (pp.122-143). New York: Routledge.

Marton, F. \& Booth, S. (1997). Learning and awareness. Mahwah, N.J.: Lawrence Erlbaum Associates.

Massey, D. (1999, April) The social place. Primary Geographer, 4-6.

May, J. (1999). Developing fieldwork in social and cultural geography: illustrations from a residential field class in Los Angeles and Las Vegas, Journal of Geography in Higher Education, 23(2) 207-225.

Morgan, J. (2001). The seduction of community: To which space do I belong? In D. Lambert \& P. Machon (Eds.) Citizenship through secondary education (pp.87-97). New York: Routledge.

Saunders, I. (1998). Who or what is school self evaluation for? NFER. Unpublished paper presented at the European Conference on Educational Research, University of Ljubljana. Slovenia.

Sidaway, J. (1992). In other worlds: On the politics of research by 'First World' geographers in the 'Third World.' Area, 24, 403-408.

Slater, F. (1994). Education through geography: Knowledge, values, understanding and culture. Geography, 79(2), 147-163. 
Tochan, F. \& Munby, H. (1993). Novice and expert teachers' time epistemology: Wave function from didactics to pedagogy, teaching and teacher education. 9(2), 205-218.

Walkington, H. (1999). Theory into practice: Global citizenship education. Sheffield, GA: The Geographical Association.
Willis, K. (2003). Fieldwork Abroad. In Rodgers, A. \& Viles, H.A. (Eds.) The students' handbook to geography (pp. 219-224). Oxford: Blackwell Publishing. 